\title{
CHLORELLA BIOMASS PRODUCTION IN ANNULAR PHOTOBIOREACTOR USING PALM OIL MILL EFFLUENT (POME): EFFECT OF HYDRODYNAMICS AND MASS TRANSFER, IRRADIANCE, AERATION RATE AND POME CONCENTRATION
}

\author{
CHENG-YAU TAN*; NIK MERIAM NIK SULAIMAN*; SOH KHEANG LOH** and SIEW-MOI PHANG ${ }^{*}$
}

\begin{abstract}
Palm oil mill effluent (POME) was used to culture Chlorella vulgaris UMACC001 in 5-litre, artificially illuminated airlift annular photobioreactors. Hydrodynamic and mass transfer characteristics were investigated for spargers perforated with different pore diameters. Maximum volumetric mass transfer coefficient and gas hold-up were achieved using sparger with $1 \mathrm{~mm}$ pores. The sparger was later used in the three-factor growth studies, i.e. irradiance, aeration rate and POME concentration, designated using fivelevel central composite design. Results showed the chlorophyll-a (Chl-a) content and specific growth rate ( $\mu$ ) ranged from 0.26 to $25.40 \mathrm{mg} \mathrm{litre}^{-1}$ and 0 to 1.033 per day, respectively. The response surface model concluded that increasing irradiance while maintaining the aeration rate and POME concentration indicates the light remained the limiting factor during experimentation. POME concentration and irradiance were found to significantly affect the Chl-a production, whereas the aeration rate was responsible for the $\mu$. The optimised biomass contained 22.0 wt\% of lipid, of which $57.0 \%$ of the fatty acids was saturated, $26.9 \%$ monounsaturated and $16.1 \%$ polyunsaturated. The predominant components, i.e. palmitic acid (C16:0), myristic acid (C14:0), stearic acid (C18:0) and eruric acid (C22:1) indicated that the biomass is a suitable feedstock for biodiesel production.
\end{abstract}

\section{Keywords: Chlorella, mass transfer, palm oil mill effluent, response surface methodology, biodiesel.}

Date received: 26 May 2016; Sent for revision: 23 July 2016; Received in final form: 19 August 2016; Accepted: 29 August 2016.

\section{INTRODUCTION}

Malaysia is one of the world's leading palm oil producer, with the mills generating more than 55

Department of Chemical Engineering, Universiti Malaya, 50603 Kuala Lumpur, Malaysia.

E-mail: meriam@um.edu.my

** Malaysian Palm Oil Board, 6 Persiaran Institusi, Bandar Baru Bangi, 43000 Kajang, Selangor, Malaysia.

‡ Institute of Ocean and Earth Sciences \& Institute of Biologial Sciences, Universiti Malaya, 50603 Kuala Lumpur, Malaysia. million tonnes of palm oil mill effluent (POME) every year and contributing the largest organic load into the waterways (Chin et al., 2013; Loh et al.,2012; 2013). Improper treatment of POME will impact the receiving water quality, endanger aquatic life and release greenhouse gases (Subramaniam et al., 2008). The increase in global demand for edible oils such as palm oil, will result in increased POME production, making it necessary to have efficient treatment systems that will contribute to the sustainable development of the palm oil industry. POME is a fairly acidic, thick and brownish non- 
toxic liquid waste with a high concentration of nitrate $\left(\mathrm{NO}_{3}^{-}\right)$, orthophosphate $\left(\mathrm{PO}_{4}^{3-}\right)$ and various essential minerals. Microalgae can help assimilate these nutrients thus reducing the eutrophication risk in receiving water bodies. Previous efforts in the cultivation of microalgae in POME have been limited to the production of aquaculture feed (Habib et al., 2003; Vairappan and Ang, 2008), while their utilisation for biodiesel production has yet to be explored. While this application is almost commercially non-existent in Malaysia, it is an attractive waste-to-product recovery approach to be introduced in parallel with the zero waste concept driven by the Malaysian government (Thani et al.,1999). It may provide an environmental-friendly and sustainable alternative to overcome the global energy crisis.

Chlorella is a single celled, spherical non-motile microscopic green alga $(2-10 \mu \mathrm{m}$ in diameter) found ubiquitously in both fresh and marine waters. It has great economic value as a source of human nutrition and pharmaceutical products since the 1970s (Richmond, 1986; Spolaore et al., 2006). Recent studies showed that Chlorella is one of the potential microalgae to be used as feedstock for biodiesel production due to its high biomass and lipid productivities and suitable fatty acid composition (Praveenkumar et al., 2014; Vello et al., 2014). Chlorella has been successfully used in bioremediating wastewaters such as rubber industry effluent (Phang et al., 2001), textile discharge (Lim et al., 2010), carpet mill effluent (Chinnasamy et al., 2010), landfill leachate (Mustafa et al., 2012) and domestic wastewater (Soydemir et al., 2016). Culturing Chlorella in wastewaters can reduce the cost of biomass production (Chinnasamy et al., 2010; Soydemir et al., 2016).

In microalgal cultivation, the most significant environmental factor is light, whereas the nutritional factors are the supply of carbon dioxide $\left(\mathrm{CO}_{2}\right)$ and nutrients. Manipulation of culture conditions and concentration of wastewater (nutrient feed) are necessary in increasing the cell growth rate. Microalgae require light energy to reduce the $\mathrm{CO}_{2}$ by oxidising the water in the photosynthesis. The effect of the light on microalgal growth depends on its intensity, quality and photoperiod. The irradiance required for microalgal photosynthesis ranges from $20-200 \mu \mathrm{mol} \mathrm{m}^{-2} \mathrm{~s}^{-1}$ and is proportional to cell density, culture depth and volume (Lavens and Sorgeloos, 1996). The $\mathrm{CO}_{2}$ is often supplied as $\mathrm{CO}_{2}$ enriched aeration to avoid carbon limitation; this can facilitate $\mathrm{pH}$ control (Zhang et al., 2002) and mixing to increase light availability to the cells. Previous studies demonstrated that biomass concentration and productivity of Chlorella increased when aeration rate was increased from 0.1 to $0.4 \mathrm{vvm}$ (volume of air per volume of culture per minute) at 2\%-6\% $\mathrm{CO}_{2}$ level (Anjos et al., 2013;
Ryu et al., 2009). POME has high solids content and a high C:N ratio, making it not amenable to aerobic digestion by microalgae (Phang and Ong, 1988). However, Chlorella has been reported to grow in low organic loading rates of POME after pre-digestion by aeration (Habib et al., 2003; Vairappan and Ang, 2008). In the present study, the use of strong bubbling with air in the annular photobioreactor allowed aerobic digestion of the POME, making the nutrients available for the microalgal growth.

The significance of the individual and interactive effects of relevant factors towards microalgal growth can be evaluated using response surface methodology (RSM). RSM is a collection of statistical and mathematical techniques, which is extensively used in many industrial processes involving several variable inputs which operate simultaneously, to study the effects of changes and mutual interactions on the process, leading to the identification of optimum conditions through designed experiments (Myers and Montgomery, 1995). It has been successfully applied in various optimisation studies in algal biotechnology, for instance, culture conditions for the mass production of microalgae (Kim et al., 2012), The $\mathrm{CO}_{2}$ biomitigation by Chlorella vulgaris (Anjos et al., 2013) and improvement of hydrodynamic properties in photobioreactors (Pirouzi et al., 2014). However, this statistical tool is not well exploited in nutrient recovery from wastewater by microalgae. RSM generates useful information that is not offered by single variable methodology when there are interactions between factors and experimental errors, in a least number of runs, thus minimising the time, effort and material resources spent.

The main objective of this study was to optimise the biomass production of $C$. vulgaris in the photobioreactor based on the best compromise between POME concentration, irradiance and aeration rate through a series of experiments designed by RSM. The interactions between these variables were further investigated to evaluate their relationship and significance in affecting the process. Thelipid content and fatty acid composition were assessed for biodiesel application.

\section{MATERIALS AND METHODS}

\section{POME Collection and Characterisation}

The raw POME originated from the Tennamaram Palm Oil Mill (Sime Darby Plantations Sdn Bhd) located in Bestari Jaya, Selangor, Malaysia. This was taken from the recovery tank before its discharge for further treatment. In the palm oil mill, the POME which still contains oil residues is usually channelled to a recovery tank where some of the oil is recovered. The POME was collected using a 
25-litre high density polyethylene container, which was sealed, brought back to the laboratory, and stored at $4^{\circ} \mathrm{C}$ before further analysis. The physical and chemical properties of POME such as $\mathrm{pH}$, chemical oxygen demand (COD), total solids (TS), total suspended solids (TSS), total volatile solids (TVS), ammoniacal-nitrogen $\left(\mathrm{NH}_{3}-\mathrm{N}\right)$, nitratenitrogen $\left(\mathrm{NO}_{3}-\mathrm{N}\right)$ and orthophosphate $\left(\mathrm{PO}_{4}^{3-}\right)$ were determined following the standard methods used for examination of water and wastewater (APHA et al., 2012).

\section{Photobioreactor Set-up}

Three 5-litre annular photobioreactors were used. Each photobioreactor consisted of dual transparent acrylic layers $(3 \mathrm{~mm}$ thickness, $66 \mathrm{~cm}$ height) with an outer layer diameter of $15 \mathrm{~cm}$ and an inner layer diameter of $9 \mathrm{~cm}$. The culture chambers were illuminated using light banks comprising six horizontal cool white fluorescent lamps at both front and back. The distance from the light source and number of illuminating lamps were adjusted to get the desired irradiance, measured using the LI-250 light meter (LI-COR). The sparger, which is placed along the base of the photobioreactor, is a looped polyethylene (PE) tube evenly perforated with 17 standard-sized pores and connected to a $1 / 8^{\prime \prime}$ stainless steel tube. The aeration was supplied from a mixed gas system comprising a diaphragm air pump and a purified $\mathrm{CO}_{2}$ tank. Hydrodynamic and mass transfer characteristics were measured for different spargers and aeration rates using distilled water at $29 \pm 1^{\circ} \mathrm{C}$ in the photobioreactors prior to growth studies.

\section{Mass Transfer, Hold-up and Reynolds Number}

Three spargers (PE tube, $7.5 \mathrm{~mm}$ inner diameter, $10 \mathrm{~mm}$ outer diameter) of different pore size $(1 \mathrm{~mm}$, $2 \mathrm{~mm}$ and $3 \mathrm{~mm}$ ) were investigated for five different aeration rates ranging from 0.2 to $1.0 \mathrm{vvm}$, in terms of volumetric mass transfer coefficient $\left(k_{\mathrm{L}} a\right)$, gas holdup $(\varepsilon)$, and Reynolds number $(R e)$. Each sparger had a total of 17 pores with $2 \mathrm{~cm}$ distance between two pores. The sparger with the best $k_{\mathrm{L}} a$ was chosen for growth studies later.

The $k_{\mathrm{L}}$ a was measured using dynamic gassingin technique (Chisti, 1989; Reyna-Velarde et al.,
2010). The distilled water was first deoxygenated by bubbling with nitrogen until the dissolved oxygen (DO) concentration dropped to near $0 \mathrm{mg}$ litre $^{-1}$. The nitrogen flow was then turned off and the gas bubbles retained were allowed to escape before the measurement started. The desired aeration rate was set and the change of DO concentration with time was recorded until the water became nearly saturated with oxygen. The $k_{\mathrm{L}}$ a was calculated from the slope of linear curve generated by Equation (1).

$$
\ln \left[\left(C^{*}-C_{0}\right) /\left(C^{*}-C\right)\right]=k_{\mathrm{L}} \mathrm{a}\left(t-t_{0}\right)
$$

where $C^{*}$ is the saturated DO concentration, $C_{0}$ and $C$ represent $\mathrm{DO}$ concentration at time, $t_{0}$ and $t$ respectively.

The $\varepsilon$ was evaluated by using the volumetric expansion method according to the Equation (2) (Reyna-Velarde et al., 2010).

$$
\varepsilon=\left(h_{\mathrm{T}}-h_{\mathrm{L}}\right) / h_{\mathrm{T}}
$$

where $h_{\mathrm{T}}$ is the overall height (liquid + gas) and $h_{L}$ is the height of liquid (without gas).

At low biomass concentration, the culture behaves like a Newtonian fluid and the Re may be calculated according to Equation (3) (Converti et al., 2006).

$$
\operatorname{Re}=\operatorname{Dv} \rho / u_{v}
$$

where $\mathrm{D}$ is the hydraulic diameter $(\mathrm{m}), v$ is the liquid velocity $\left(\mathrm{m} \mathrm{s}^{-1}\right), \rho$ is the liquid density $\left(\mathrm{kg} \mathrm{m}^{-3}\right)$ and $u_{v}$ is the liquid viscosity $\left(\mathrm{kg} \mathrm{m}^{-1} \mathrm{~s}^{-1}\right)$.

\section{Microalgae and Culture Conditions}

The microalga used was Chlorella vulgaris Beijerinck UMACC001 obtained from the Universiti Malaya Algae Culture Collection (UMACC), Kuala Lumpur, Malaysia. The alga was previously isolated from a fish pond at the experimental farm at the Universiti Malaya. The growth studies involved the preparation of POME in different concentrations as set by the RSM design (Table 1) by diluting with appropriate volumes of distilled water. Each photobioreactor was inoculated with C. vulgaris UMACC001 to give an initial chlorophyll- $a$

TABLE 1. CODED AND ACTUAL LEVEL OF THE THREE INDEPENDENT VARIABLES

\begin{tabular}{lcccccc}
\hline Variable & Symbol & \multicolumn{3}{c}{ Level } \\
\cline { 3 - 6 } & & $\mathbf{- 1 . 6 8}$ & $\mathbf{- 1}$ & $\mathbf{0}$ & $\mathbf{+ 1}$ & $\mathbf{+ 1 . 6 8}$ \\
\hline Irradiance $\left(\mu \mathrm{mol} \mathrm{m}^{-2} \mathrm{~s}^{-1}\right)$ & $X_{1}$ & 12.8 & 40.0 & 80.0 & 120.0 & 147.2 \\
Aeration rate $(\mathrm{vvm})$ & $X_{2}$ & 0.00 & 0.1 & 0.3 & 0.5 & 0.63 \\
POME $^{\mathrm{a}}(\%)$ & $X_{3}$ & 0.65 & 2.0 & 4.0 & 6.0 & 7.35 \\
\hline
\end{tabular}

Note: ${ }^{a}$ Palm oil mill effluent (POME) concentration. 
(Chl- $a$ ) content of $1.06 \pm 0.16 \mathrm{mg}$ litre $^{-1}$. The $\mathrm{pH}$ was maintained at $6.8 \pm 0.2$ by fixing the rate of aeration with $5 \% \mathrm{CO}_{2}$ enriched air to provide the desired $\mathrm{pH}$ range. The experiments were carried out in triplicates for 12 days on 12:12-hr light-dark cycle with a culture temperature of $29 \pm 1^{\circ} \mathrm{C}$.

\section{Growth Kinetics}

Growth was monitored at two-day intervals based on Chl-a content using the spectrophotometric equation from Equation (4) (Strickland and Parsons, 1972). Dry weight was not chosen for growth studies because of the interference from large amount of suspended solids in POME.

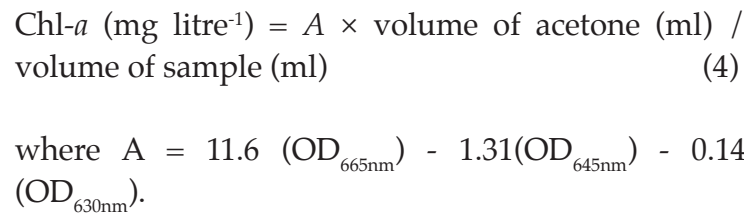

The specific growth rate $(\mu)$ was calculated according to Equation (5).

$$
\mu\left(\text { day }^{-1}\right)=\left(\ln N_{2}-\ln N_{1}\right) /\left(t_{2}-t_{1}\right)
$$

where $N_{1}$ and $N_{2}$ are Chl- $a$ contents at time, $t_{1}$ and $t_{2}$ respectively during the exponential phase.

\section{Determination of Total Lipids and Fatty Acid Compositions}

The culture was filtered using $0.45 \mu \mathrm{m}$ filters (Whatman GF/C, $47 \mathrm{~mm}$ ) and total lipids were extracted in methanol-chloroform solution and measured by gravimetric method (Bligh and Dyer, 1959). Transesterification of lipids were done in the mixture of $\mathrm{HCl}$, methanol, toluene and water heated at $100^{\circ} \mathrm{C}$ using dry bath (MD-02N-220, Major Science, USA) for $1 \mathrm{hr}$ (Ichihara and Fukubayashi, 2010). The extracted fatty acid methyl esters (FAME) were identified using Agilent 7820A Gas Chromatography in accordance to the method performed by Vello et al. (2014) with the adding of C7:0 (Sigma ${ }^{\circledR}$, USA) as internal standard for quantification.

\section{Response Surface Methodology}

The experimental design and statistical analysis were assessed using Design Expert 7.0 software. A total of 17 runs including three replicates (control) of the centre point were carried out based on the five-level central composite design (CCD) for the three chosen independent variables, i.e. irradiance, aeration rate and POME concentration. The levels of variables are shown in Table 1. Optimal conditions for maximising the biomass production were predicted by solving the second-order polynomial equation, Equation (6) and by analysing the response surface contour plots.

$$
Y=B_{0}+\sum B_{i} X_{i}+\sum B_{i i} X_{i}^{2}+\sum B_{i j} X_{i} X_{j}
$$

where $Y$ represents the predicted response, $B_{0}$ is the interception coefficient, $B_{i^{\prime}} B_{i i}$ and $B_{i j}$ are the regression coefficients for the three variables, $X_{i}$ (linear term), $X_{i}^{2}$ (quadratic term) and $X_{i} X_{j}$ (interaction term) respectively. Analysis of variance (ANOVA) was conducted to identify the statistical significance of the model, each factor and their interaction by means of $F$-test and its associated probability, $p$ value.

\section{RESULTS AND DISCUSSION}

\section{Characteristics of POME and its Suitability as Substrate for Microalgal Growth}

In order to design the RSM experiments, it is necessary to identify the characteristics of the initial POME used. Results are shown in Table 2 along with the data range recorded by the Malaysian Palm Oil Board (MPOB). POME is a viscous liquid of brownish colour. The low $\mathrm{pH}(4.5 \pm 0.01)$ of the POME used for

TABLE 2. CHARACTERISTICS OF PALM OIL MILL EFFLUENT FROM TENNAMARAM PALM

\begin{tabular}{|c|c|c|}
\hline Parameter & $\begin{array}{c}\text { Value }^{\mathrm{a}} \\
\text { (present study) }\end{array}$ & $\begin{array}{c}\text { Range }^{\mathrm{a}} \\
\text { (Thani } \text { et al., 1999) }\end{array}$ \\
\hline $\mathrm{pH}$ & $4.51 \pm 0.01$ & 3.4-5.2 \\
\hline Chemical oxygen demand (COD) & $74900 \pm 625$ & 15 000-100 000 \\
\hline Total solids (TS) & $60176 \pm 432$ & $11500-79000$ \\
\hline Total suspended solids (TSS) & $15350 \pm 606$ & $5000-54000$ \\
\hline Total volatile solids (TVS) & $49004 \pm 175$ & $9000-72000$ \\
\hline Ammoniacal-nitrogen $\left(\mathrm{NH}_{3}-\mathrm{N}\right)$ & $64 \pm 9$ & 4-80 \\
\hline Nitrate-nitrogen $\left(\mathrm{NO}_{3}-\mathrm{N}\right)$ & $453 \pm 15$ & - \\
\hline Total nitrogen & - & $180-1400$ \\
\hline Orthophosphate $\left(\mathrm{PO}_{4}^{3-}\right)$ & $504 \pm 10$ & - \\
\hline
\end{tabular}
OIL MILL IN SELANGOR, MALAYSIA

Note: ${ }^{a}$ Units in mg litre ${ }^{-1}$ except $\mathrm{pH}$. 
the studies was due to the presence of organic acids (Wu et al., 2010). It contained high TS (60 176 \pm 432 mg litre ${ }^{-1}$ ) and consequently high COD (74 900 \pm 625 mg litre $\left.{ }^{-1}\right)$. These solids are mainly organic sludge consisting of plant residues originated from the oil extraction processes. This value is consistent with the high TVS content (49 004 $\pm 175 \mathrm{mg} \mathrm{litre}^{-1}$ ), which depicts the amount of organic matter present. The $\mathrm{NO}_{3}-\mathrm{N}$ content $\left(453 \pm 15 \mathrm{mg}_{\text {litre }}{ }^{-1}\right)$ is relatively lower compared to COD and $\mathrm{PO}_{4}^{3-}$ content $(504 \pm 10$ $\mathrm{mg}$ litre $\left.^{-1}\right)$. The high COD-to-nitrogen ratio, acidic nature, and dark colour reduced light availability, which resulted in poor microalgal growth in POME (Phang and Ong, 1988). The $\mathrm{pH}$ has to be adjusted to 6.8 to favour the growth and metabolism of $C$. vulgaris UMACC001 (Phang and Chu, 1999). To overcome light limitation, the POME had to be diluted. Reducing the POME concentration to $4 \%$ $6 \%$ still provides sufficient $\mathrm{NO}_{3}-\mathrm{N}$ and $\mathrm{PO}_{4}{ }^{3-}$ contents for cultivating C. vulgaris UMACC001, as compared that of Bold's Basal Medium (Nichols and Bold, 1965). However, the POME characteristics could have great variation depending on the cropping season, quality of fruit, mill operation and processing facility, climate, and dilution (water usage) (Wu et al., 2010). Therefore, nutrient levels in POME should be identified prior to cultivation of microalgae to ensure they are available in suitable quantity when dilution is made, while maintaining sufficient light availability at low solids concentration. Waste grown microalgae have been reported to require C:N:P ratio of 56:9:1 (Habib et al., 2003).

\section{Hydrodynamic and Mass Transfer Characteristics}

The hydrodynamic and mass transfer characterisation comprised the influence of the aeration rate on the gas hold-up $(\varepsilon)$ and volumetric mass transfer coefficient $\left(k_{\mathrm{L}} a\right)$. The $\varepsilon$ is the fraction of liquid volume displaced by the aeration while $k_{\mathrm{L}} a$ indicates the rate of gas diffused into the liquid phase, whereas the $R e$ determines the degree of turbulence of the photobioreactor. Figure 1a shows the relationship between $\varepsilon$ and aeration rate for the spargers of three different pore sizes, in the photobioreactor. Generally, the $\varepsilon$ was nearly linear with respect to the aeration rate. It increased with increasing aeration rate and decreasing pore size. The $\varepsilon$ determines the gas residence time and quantity that subsequently affects the $k_{\mathrm{L}} a$. High $\varepsilon$ increases the amount of gas contact with liquid which in turn increases the dissolution of the gas and $k_{\mathrm{L}} a$. Therefore, the behaviour of $k_{\mathrm{L}} a$ dependent on aeration rate (Figure 1c) was found concordantly with the observations for $\varepsilon$ (Figure $1 a$ ). The $\varepsilon$ and $k_{\mathrm{L}} a$ values were similar to those reported by Sierra et al. (2008) in a flat plate photobioreactor. In the sparger with larger pore size, bubble size increases and reduces the interfacial contact area preventing an
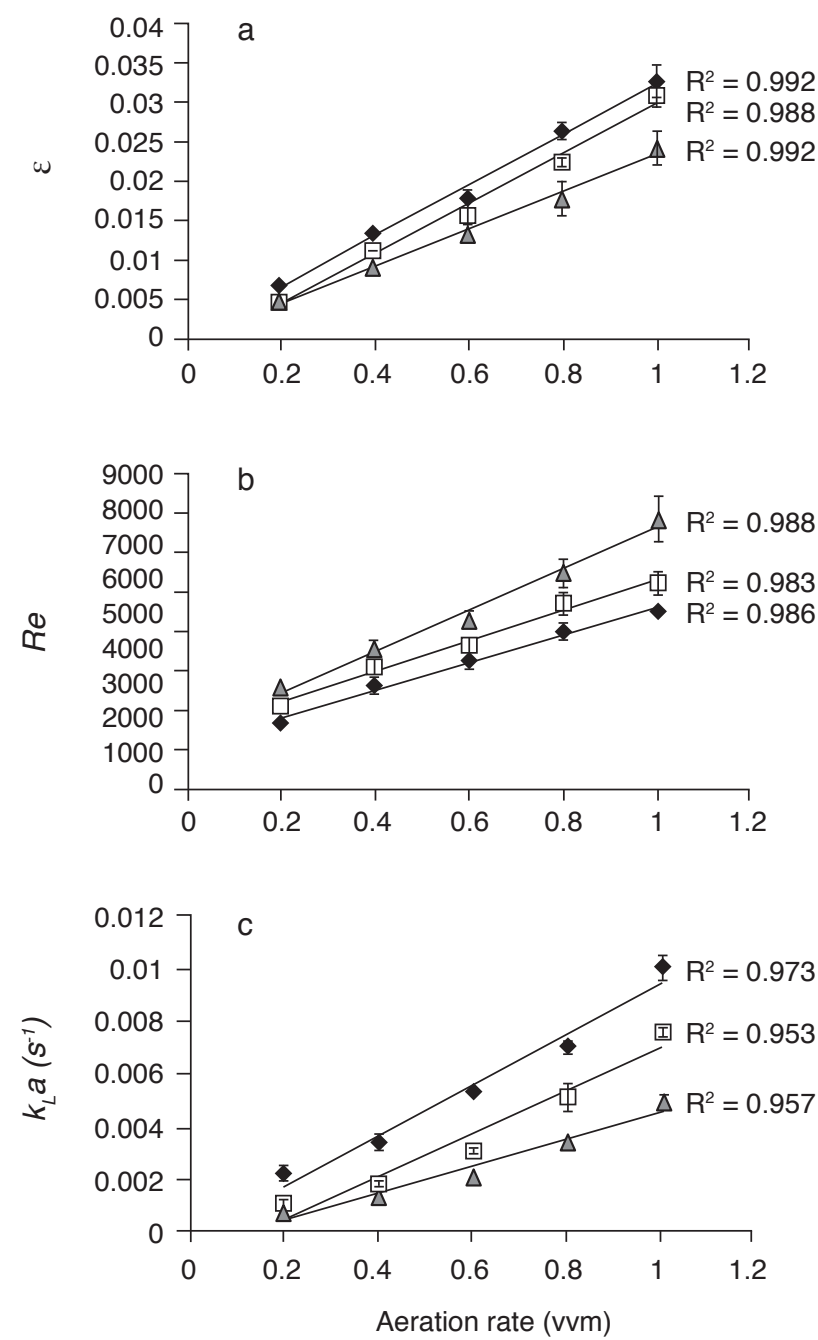

Figure 1. Influence of the aeration rate in the (a) gas hold-up (c); (b) Reynolds number (Re); and (c) volumetric mass transfer coefficient

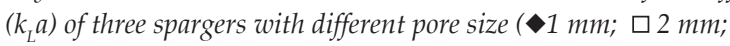

- $3 \mathrm{~mm}$ ) in the annular photobioreactor.

increase for $k_{\mathrm{L}} a$. Large bubble size also enhances its ascending speed, causing a decrease on its residence time in the liquid and hence, giving lower value of $\varepsilon$. An addition of activated carbon particles or other fine particles such as microalgae cells could diminish the coalescence leading to small bubble formation and increase in interfacial area, which favours the $\varepsilon$ and $k_{\mathrm{L}} a$ (Reyna-Velarde et al., 2010). Figure $1 b$ shows the effect of aeration rate on Re for different spargers and the slopes were all linearly proportional. The values of Re rose with the increase of both aeration rate and pore size. Results showed all the spargers provided a turbulent flow (Re $>$ 2100 ) except for aeration rate below $0.2 \mathrm{vvm}$. This indicates that at least $0.2 \mathrm{vvm}$ would be required to assure turbulence in this photobioreactor and consequently maintain the homogenous mixing while preventing settlement. This study optimised the mass transfer at low flow rates (less than $1 \mathrm{vvm}$ ) to minimise the power consumption for the working system and shear damage on the cell. Sparger A was 
selected for the biomass study since it provided larger $k_{\mathrm{L}} a$ than others at the desired turbulence. High DO concentration close to the air saturation point resulted from high $k_{\mathrm{L}} a$ may negatively affect the cell. However, this effect is negligible because microalgae can actually tolerate up to four times this value (Sierra et al., 2008). An aerated culture may also eliminate the excessive oxygen accumulation during active photosynthesis. A $k_{\mathrm{L}} a$ of $0.006 \mathrm{~s}^{-1}$ would suffice to keep the DO below 300\% (Sierra et al., 2008), equivalent to $0.66 \mathrm{vvm}$ (Sparger A) in this study.

\section{Response Surface Model and ANOVA}

Table 3 shows the variation of Chl- $a$ content produced by $C$. vulgaris UMACC001 cultivated under different designed conditions. The minimum $\left(0.26 \pm 0.03 \mathrm{mg}\right.$ litre $\left.^{-1}\right)$ and maximum values $\left(25.40 \pm 0.29 \mathrm{mg}\right.$ litre $\left.^{-1}\right)$ were recorded at run \#14 and run \#9 respectively. Multiple regression analysis was applied to these experimental results to obtain the coefficient for each variable, thus giving Equation (7) as follows:

$$
\begin{aligned}
& Y=19.68+5.56 X_{1}+1.04 X_{2}+3.04 X_{3}-0.12 X_{1} X_{2}+ \\
& 3.37 X_{1} X_{3}+0.58 X_{2} X_{3}-1.61 X_{1}^{2}-1.49 X_{2}^{2}-4.51 X_{3}^{2} \quad(7)
\end{aligned}
$$

where $Y$ is the predicted Chl- $a$ content (mg litre $\left.^{-1}\right), X_{1}, X_{2}$ and $X_{3}$ are the coded values of the three independent variables, i.e. irradiance, aeration rate and POME concentration (Table 1).

The results from analysis of F-test (ANOVA), which implies the statistical reliability of the quadratic model, are summarised in Table 4. The coefficient of determination, R2 (0.9629) was close to 1.0 , indicating that more than $96 \%$ of the variation of observed values could be interpreted by the predicted values. The predicted $R^{2}$ of 0.7217 was in reasonable agreement with the adjusted R2 of 0.9152 . With the $p$ value $(0.0003)$ lower than $0.05(95 \%$ confidence level) and the non-significant lack-of-fit $(\mathrm{p}=0.0575)$ relative to the pure error, the quadratic model, i.e. Equation (7) was valid to represent the study. These results showed that the model described the relationship between independent variables and the response (Chl- $a$ content) very well.

The model showed a coefficient of 19.68 (coded value, Table 4) obtained from the predicted values at centre points as control of the experiments. Meanwhile, the coefficient of the corresponding variable indicated its impact level on the Chl- $a$ content. The larger the coefficient, the more is its effect, regardless of the (+) or (-) sign which merely shows the direction of deviation from the centre. In this experiment, irradiance $\left(X_{1}\right)$ was observed to have the highest coefficient value (5.56), whereas the interaction between irradiance and aeration rate $\left(X_{1} X_{2}\right)$ had the lowest value. The factors are arranged in decreasing order of impact as follows: $X_{1}>X_{3}^{2}>X_{1} X_{3}>X_{3}>X_{1}^{2}>X_{2}^{2}>X_{2}>X_{2} X_{3}>X_{1} X_{2}$. The order

TABLE 3. MATRIX OF EXPERIMENTAL CENTRAL COMPOSITE DESIGN (CCD) WITH EXPERIMENTAL

\begin{tabular}{|c|c|c|c|c|c|c|}
\hline \multirow[t]{2}{*}{ Run order } & \multirow[t]{2}{*}{$\begin{array}{c}\text { Irradiance } \\
\left(X_{1}\right)\end{array}$} & \multirow[t]{2}{*}{$\begin{array}{l}\text { Aeration rate } \\
\qquad\left(\mathrm{X}_{2}\right)\end{array}$} & \multirow[t]{2}{*}{$\begin{array}{l}\text { POME }^{\mathrm{a}} \\
\qquad\left(\mathrm{X}_{3}\right)\end{array}$} & \multicolumn{2}{|c|}{$\begin{array}{l}\text { Maximum Chl- } a^{\mathrm{b}} \\
\left.\text { content (mg litre }{ }^{-1}\right)\end{array}$} & \multirow[t]{2}{*}{$\begin{array}{c}\mu^{c} \\
\text { (per day) }\end{array}$} \\
\hline & & & & Experimental & Predicted & \\
\hline 1 & -1 & +1 & -1 & $7.19 \pm 0.13$ & 7.41 & $0.408 \pm 0.023$ \\
\hline 2 & -1 & +1 & +1 & $7.02 \pm 0.25$ & 7.90 & $0.291 \pm 0.019$ \\
\hline 3 & -1 & -1 & -1 & $8.72 \pm 0.22$ & 6.26 & $0.311 \pm 0.035$ \\
\hline 4 & -1 & -1 & +1 & $5.15 \pm 0.14$ & 4.44 & $0.246 \pm 0.032$ \\
\hline 5 & +1 & +1 & -1 & $11.01 \pm 0.20$ & 11.56 & $1.033 \pm 0.039$ \\
\hline 6 & +1 & +1 & +1 & $23.25 \pm 0.95$ & 25.54 & $0.727 \pm 0.021$ \\
\hline 7 & +1 & -1 & -1 & $11.92 \pm 0.51$ & 10.87 & $0.693 \pm 0.018$ \\
\hline 8 & +1 & -1 & +1 & $22.92 \pm 2.01$ & 22.54 & $0.667 \pm 0.024$ \\
\hline 9 & +1.68 & 0 & 0 & $25.40 \pm 0.29$ & 24.48 & $0.788 \pm 0.012$ \\
\hline 10 & -1.68 & 0 & 0 & $4.63 \pm 0.04$ & 5.78 & $0.357 \pm 0.024$ \\
\hline 11 & 0 & +1.68 & 0 & $19.62 \pm 0.87$ & 17.20 & $0.903 \pm 0.024$ \\
\hline 12 & 0 & -1.68 & 0 & $11.05 \pm 0.07$ & 13.71 & $0.457 \pm 0.024$ \\
\hline 13 & 0 & 0 & +1.68 & $13.35 \pm 0.14$ & 12.03 & $0.508 \pm 0.049$ \\
\hline 14 & 0 & 0 & -1.68 & $0.26 \pm 0.03$ & 1.81 & 0 \\
\hline 15 & 0 & 0 & 0 & $19.86 \pm 0.33$ & 19.68 & $0.881 \pm 0.032$ \\
\hline 16 & 0 & 0 & 0 & $20.22 \pm 0.60$ & 19.68 & $0.863 \pm 0.040$ \\
\hline 17 & 0 & 0 & 0 & $18.99 \pm 0.52$ & 19.68 & $0.857 \pm 0.060$ \\
\hline
\end{tabular}
AND PREDICTED RESULTS FOR THE STUDY 
TABLE 4. ANALYSIS OF VARIANCE (ANOVA) AND REGRESSION COEFFICIENT ESTIMATE FOR THE BIOMASS PRODUCTION MODEL

\begin{tabular}{|c|c|c|c|c|c|c|c|c|}
\hline \multirow[t]{2}{*}{ Source } & \multirow{2}{*}{$\begin{array}{l}\text { Sum of } \\
\text { square }\end{array}$} & \multirow{2}{*}{$\begin{array}{l}\text { Degree of } \\
\text { freedom }\end{array}$} & \multirow{2}{*}{$\begin{array}{l}\text { Mean } \\
\text { square }\end{array}$} & \multicolumn{2}{|c|}{ Coefficient } & \multirow{2}{*}{$\begin{array}{c}\text { Standard } \\
\text { error }\end{array}$} & \multirow[t]{2}{*}{$F$ value } & \multirow{2}{*}{$\begin{array}{c}p \text { value } \\
(\text { Probability }>\text { F })\end{array}$} \\
\hline & & & & Coded & Actual & & & \\
\hline Model & 8870.44 & 9 & 98.60 & 19.68 & -12.030 & 1.27 & 20.19 & $0.0003^{a}$ \\
\hline$X_{1}$ & 4220.39 & 1 & 422.39 & 5.56 & 0.140 & 0.60 & 86.50 & $<0.0001^{\mathrm{a}}$ \\
\hline$X_{2}$ & 14.71 & 1 & 14.71 & 1.04 & 22.950 & 0.60 & 3.01 & 0.1262 \\
\hline$X_{3}$ & 1260.20 & 1 & 126.20 & 3.04 & 6.730 & 0.60 & 25.84 & $0.0014^{\mathrm{a}}$ \\
\hline$X_{1} X_{2}$ & 0.11 & 1 & 0.11 & -0.12 & 0.014 & 0.78 & 0.022 & 0.8871 \\
\hline$X_{1} X_{3}$ & 90.99 & 1 & 90.99 & 3.37 & 0.004 & 0.78 & 18.63 & $0.0035^{\mathrm{a}}$ \\
\hline$X_{2} X_{3}$ & 2.69 & 1 & 2.69 & 0.58 & 1.450 & 0.78 & 0.55 & 0.4820 \\
\hline$X_{1}^{2}$ & 29.12 & 1 & 29.12 & -1.61 & 0.001 & 0.66 & 5.96 & $0.0446^{\mathrm{a}}$ \\
\hline$X_{2}^{2}$ & 25.17 & 1 & 25.17 & -1.49 & -37.350 & 0.66 & 5.15 & 0.0575 \\
\hline$X_{3}^{2}$ & 229.29 & 1 & 229.29 & -4.51 & -1.130 & 0.66 & 46.96 & $0.0002^{\mathrm{a}}$ \\
\hline Residual & 34.18 & 7 & 4.88 & - & - & - & - & - \\
\hline Lack-of-fit & 33.38 & 5 & 6.68 & - & - & - & 16.70 & 0.0575 \\
\hline Pure error & 0.80 & 2 & 0.40 & - & - & - & - & - \\
\hline $\begin{array}{l}\text { Corrected } \\
\text { total }\end{array}$ & 921.62 & 16 & - & - & - & - & - & - \\
\hline
\end{tabular}

Note: $R^{2}=0.9629$, Adj. $R^{2}=0.9152$, Pred. $R^{2}=0.7217$, C.V. $=16.29 \%$.

$X_{1}=$ irradiance; $X_{2}=$ aeration rate; $X_{3}=$ palm oil mill effluent concentration.

a Statistical significant, $p<0.05$.

for coefficient in actual value was not in accordance with that of coded value as it involved dissimilar range and unit.

The results were further confirmed by the $p$ value of each variable tested. All parameters were statistically significant in affecting the biomass production except for aeration rate $\left(X_{2}\right)$ and its interactive terms and quadratic term. One should note that it could be due to the interval value between levels set for each variable during the preliminary design stage. Its effect on the biomass production is further discussed in the next section. Decreasing $p$ value indicates increasing significance and reducing probability of error occurrence due to noise. The order of significance for the variables was slightly different compared to the impact mentioned earlier, i.e. $X_{1}>X_{3}^{2}>X_{3}>X_{1} X_{3}>X_{1}^{2}>X_{2}^{2}>X_{2}>X_{2} X_{3}>X_{1} X_{2}$. In this case, $X_{1} X_{3}$ came after $X_{3}$ but it expressed greater impact than $X_{3}$ probably because of the combined effects from both $X_{1}$ and $X_{3}$.

\section{Effect of the Variables on the Biomass Production}

Overlapping of the curves in Figure 2 suggested the biomass can be increased at high-level irradiance by fixing the POME concentration and aeration rate at the central region, which was well described by run \#9. Compared to Figures $2 a$ and $2 c$, Figure $2 b$ showed that the highest biomass was obtained at higher POME concentration, extended level of irradiance under constant aeration rate at control condition. This finding corresponded well with a previous study performed by $\mathrm{Ng}$ et al. (2014) showing that C. vulgaris UMACC001 used in this study is tolerant to high irradiance. This strain is capable of photoprotection against high irradiance by releasing excess light harnessed as heat through the non-photochemical quenching (NPQ) mechanism. Insufficient light led to cell stress and growth limitation, whereas too high or too low POME concentration resulted in reduced light availability and nutrient deficiency, respectively. The dark colour of the POME limited the light availability in the photobioreactor for photosynthesis thereby giving low specific growth rate. This could be observed from Figures $2 b$ and $2 c$ where the growth started to decline at concentration of more than 5\% POME. It happened similarly in a study of Chlorella pyrenoidosa cultivated under the continuous illumination with $150 \mu \mathrm{mol} \mathrm{m} \mathrm{m}^{-2} \mathrm{~s}^{-1}$ and 10-time diluted POME (Ponraj and Din, 2013). The higher concentration of POME in the reported study resulted in only a four-fold increase in biomass after 14 days; this is significantly lower than the 20-fold increase obtained in our study. Habib et al. (2003) reported higher growth of C.vulgaris in $10 \%$ POME than at 5\% POME, whereas the growth of C. vulgaris UMACC001 in the present study peaked at 4\%-6\% POME, as shown in Figures $2 b$ and $2 c$. This difference was probably due to fact that in the previous study, a 16-day aerobic digestion of the POME was used to achieve low COD: $\mathrm{N}$ ratio and solids content prior to growing the microalgae. However, with the supply of strong irradiance and aeration with $\mathrm{CO}_{2}$ enriched air, our present study obtained $25.40 \mathrm{mg}$ litre $^{-1}$ Chl- $a$ which is significantly higher than the 14.71 mg litre ${ }^{-1}$ Chl- $a$ reported by Habib et al. (2003). In another study, Chlorella sorokiniana achieved higher Chl- $a$ content in the unsterilised raw POME than that in the autoclave-sterilised one, suggesting that 
a

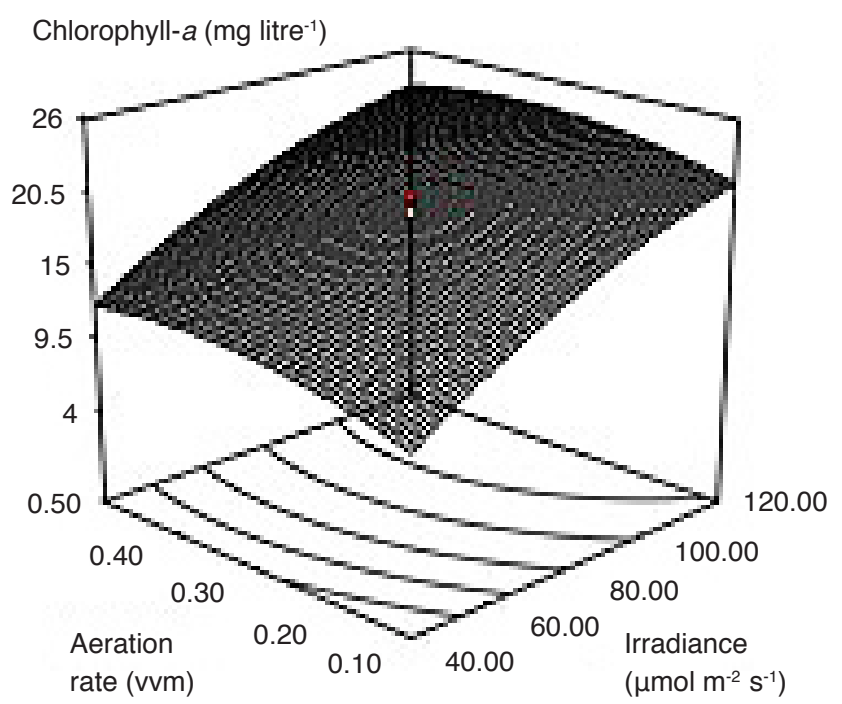

b

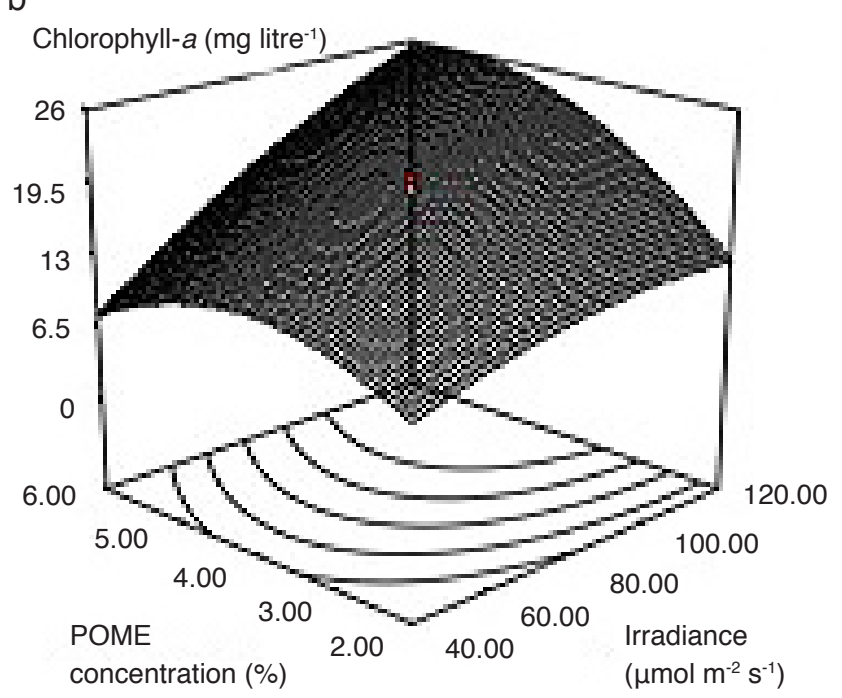

C

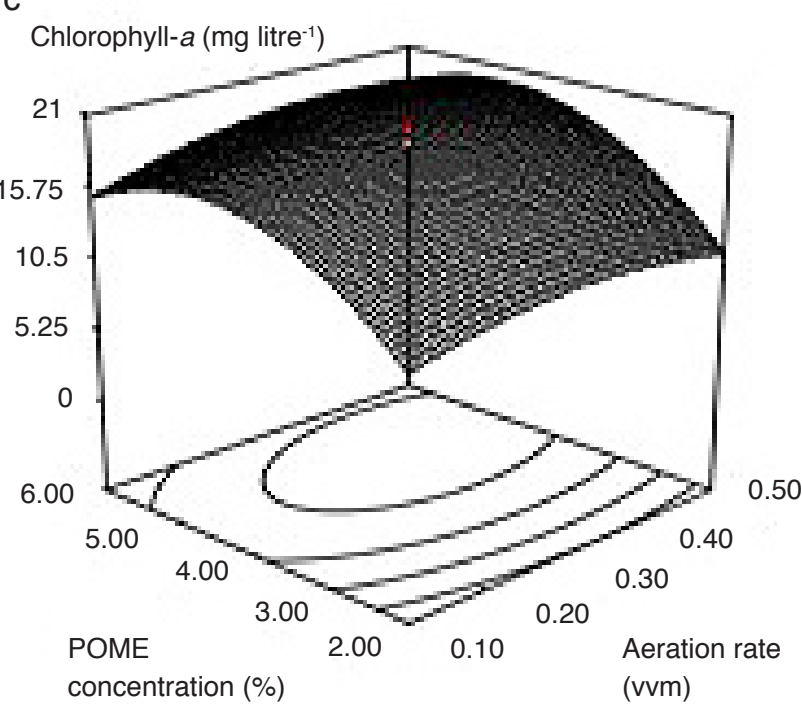

Figure 2. The 3D surface plot showing the chlorophyll-a production of C. vulgaris UMACC001 as an effect of (a) aeration rate and irradiance; (b) palm oil mill effluent (POME) concentration and irradiance; (c) $P O M E$ concentration and aeration rate. The other variable in each plot was kept at centre point.
POME may contain a mixed microbial consortium which provides a diversity of biocompounds that may stimulate microalgal growth (Nwuche et al., 2014). POME has been reported to contain a growth inhibitor in the form of tannic acid (Neoh et al., 2013), which is known to be a potential metal ion chelator, protein precipitating agent and biological antioxidant (Palanisami et al., 2012). The polyaromatic compound forms stable complexes with bivalent iron $(\mathrm{Fe})$ ions, preventing the $\mathrm{Fe}$ assimilation for the synthesis of related proteins and pigments in microalgal cells (Sukumaran et al., 2014). However, in the present study, the light reducing effect may be greater than the effect of tannic acid as the ratio of tannin to iron Fe should be constant at every concentration, without any additional nutrients being supplied.

The interaction between the two significant factors, that is, POME concentration and irradiance, on the biomass growth is depicted in Figure $2 b$. Increasing irradiance at $2 \%$ POME had very little effect on the Chl- $a$ content produced. However, when the POME was fixed at high concentration $(6 \%)$, an increase in irradiance significantly increased the biomass growth. The effect of irradiance is therefore dependent on the POME concentration. This implied that at low POME concentration, light is available in abundance but the nutrient content becomes the growth limiting factor. Conversely, when the nutrients are sufficient at high POME concentration, additional irradiance is required to offset the high solids content in POME and the self-shading effect of increased biomass. In outdoor cultures, especially in the tropical regions, abundance of light may be a limiting factor due to photoinhibition. In this environment, microalgal culture in POME at the right concentration, may be a possible strategy to avoid photoinhibition.

Figure 3 illustrated that the specific growth rate, $\mu$ obtained at high aeration rate was relatively better than at low aeration rate, indicating that the photosynthetic activity was enhanced. Increasing aeration rate improved the $k_{\mathrm{L}} a$ and enhanced the dissolution of $\mathrm{CO}_{2}$ in water (Fan et al., 2007), resulting in more available dissolved inorganic carbons (DIC) to be assimilated for the carboxilating activity in photosynthesis and simultaneously depressed the oxygenating activity of Rubisco in photorespiration (Yang and Gao, 2003). This suggested that $C$. vulgaris UMACC001 has high affinity for $\mathrm{CO}_{2}$ and high reaction rate of carbonic anhydrase, both contributing to the enhanced photosynthesis. Aeration can also prevent a gradient in irradiance from the periphery to the inner region of the photobioreactor. The cells exposed to high irradiance at the periphery will move from the zone of excess light to the internal dark zone for dissipating the excess photons in order to reduce photooxidative damage (Sforza et 


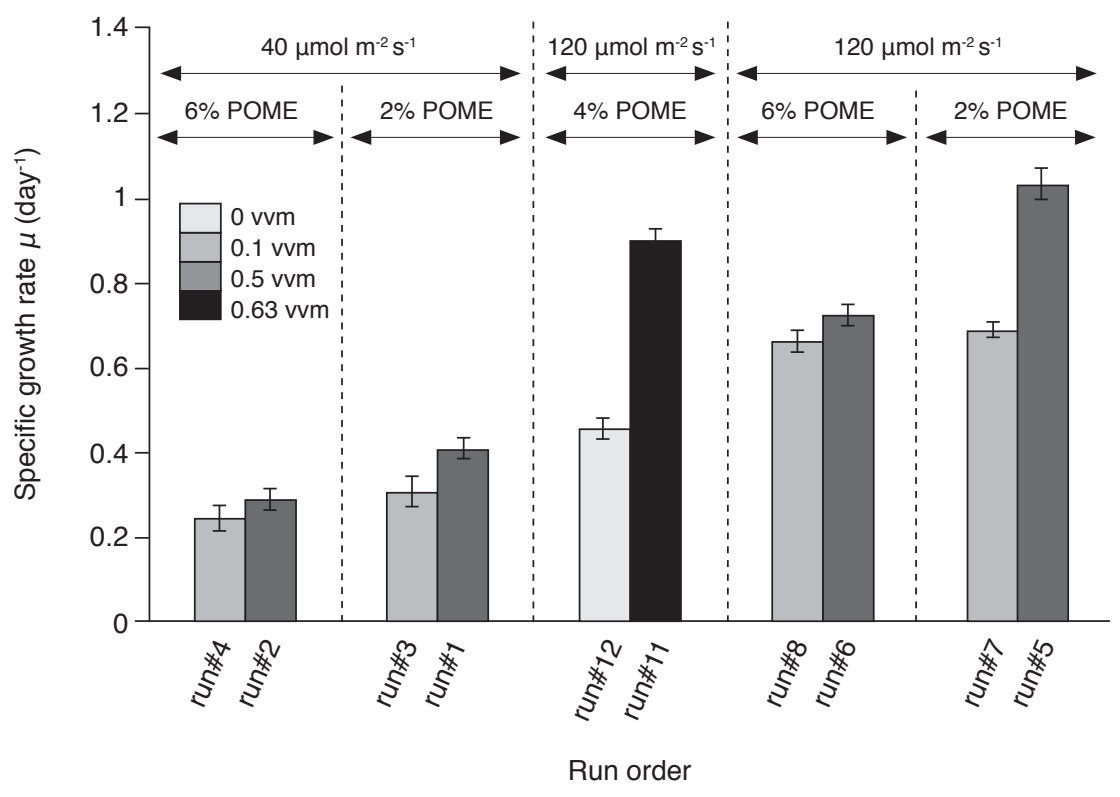

Figure 3. Comparison of specific growth rate of $\mathrm{C}$. vulgaris UMACC001 between two experiments at different aeration rate under constant palm oil mill effluent (POME) concentration and irradiance. For each pair of columns, the darker-shaded column has the higher aeration rate.

al., 2012). Nevertheless, results showed that aeration rate was not significant in maximising Chl- $a$ content ( $p>0.05)$. Despite giving higher growth rate, run \#1 and run \#5 with stronger aeration, as compared to run \#3 and run \#7, respectively, which gave lower final Chl-acontent probably due to the deficiency of nutrients at low POME concentration. Yang and Gao (2003) also reported that increased DIC could enhance the growth rate of green microalgae, even when the $\mathrm{N}$ and $\mathrm{P}$ contents were at growthlimiting levels. This is likely to be related to the compensation of elevated DIC for low $\mathrm{N}$ condition and the associated low energy demand for $\mathrm{N}$ uptake. Furthermore, Kim et al. (2014) discovered that under a given irradiance, $C$. vulgaris did not grow significantly with further increase in DIC concentration above $144 \mathrm{mg} \mathrm{Clitre}^{-1}$. It was suggested that the DIC concentration is the limiting factor for initial growth at low biomass density, but the light availability affects the final biomass concentration at later growth stage due to the shading effect in high cell density, similar to the observations obtained in the present study. Alternatively, high aeration of $\mathrm{CO}_{2}$ induces a drop in $\mathrm{pH}$ and the activity of carbonic extracellular anhydrase (CAext). This would affect the equilibrium of catalytic conversion between $\mathrm{CO}_{2}$ and $\mathrm{HCO}_{3}^{-}$by CAext, thus inhibiting the growth (Tang et al., 2011; Yang and Gao, 2003). Fan et al. (2007) suggested that the aggravated gas flow rate tend to lower the bubble retention time, leading to the escape of $\mathrm{CO}_{2}$ to the outlet before efficient mixing occurred. Therefore, the supplied gas could not be efficiently used by the cell and the Chl- $a$ content peaked at 0.3-0.5 vvm as shown in Figures $2 a$ and $2 c$. A $k_{\mathrm{L}} a$ of $0.001-0.0017 \mathrm{~s}^{-1}$ for $5 \% \mathrm{CO}_{2}$-air gas (corresponds to 0.11-0.19 vvm for Sparger A) would be sufficient to overcome $\mathrm{CO}_{2}$ limitation in the photobioreactor (Zhang et al., 2002). It is necessary to optimise the aeration conditions as low $\mathrm{CO}_{2}$ utilisation efficiency at high aeration rate could be uneconomical for commercial production (Ryu et al., 2009; Zhang et al., 2002). In addition, an aeration rate above $0.5 \mathrm{vvm}$ may reduce the growth of $C$. vulgaris due to the shear damage by high aeration (Zheng et al., 2012). This shear stress could be reduced by using sodium bicarbonate $\left(\mathrm{NaHCO}_{3}\right)$ as a buffer to keep the DIC concentration high at low aeration rate without affecting the $\mathrm{pH}$ of culture conditions (Kim et al., 2014). Sodium ion concentration should be kept below 60 millimolars to prevent growth inhibition of freshwater microalgae. Apart from that, $\mathrm{CO}_{2}$ could also affect the light saturating point and the recovery from photoinhibition through a repair mechanism (Yang and Gao, 2003). These suggested the response of microalgae to $\mathrm{CO}_{2}$ is complicated and involves interactions with other factors such as light and nutrient levels as presented in this study.

\section{Optimisation and Verification}

The optimum values for each variable can be obtained by the differentiation of Equation (7) to find the maximum point or estimated using the 'point optimisation' method. By using the latter, technique in the design software, the predicted optimal condition was carried out to validate the statistical model. Table 5 shows a significant increase in Chl- $a$ production with $27.38 \pm 0.09 \mathrm{mg} \mathrm{litre}^{-1}$, which is higher than the best conditions designed earlier $\left(25.40 \pm 0.29 \mathrm{mg}\right.$ litre $\left.^{-1}\right)$. The result was in agreement with the predicted Chl- $a$ value suggesting that Equation (7) was valid for biomass production. This 
TABLE 5. OPTIMAL CONDITIONS FOR BIOMASS PRODUCTION

\begin{tabular}{|c|c|c|c|c|c|}
\hline Variables & $\begin{array}{c}\text { Irradiance } \\
\left(\mu \mathrm{mol} \mathrm{m}^{-2} \mathrm{~s}^{-1}\right)\end{array}$ & $\begin{array}{l}\text { Aeration rate } \\
(\mathrm{vvm})\end{array}$ & $\begin{array}{c}\text { POMEa } \\
(\%)\end{array}$ & $\begin{array}{l}\text { Chl- } a^{\mathrm{b}} \text { content } \\
\left(\mathrm{mg} \text { litre }^{-1}\right)\end{array}$ & $\begin{array}{c}\mu \mathrm{c} \\
\text { (per day) }\end{array}$ \\
\hline Designed by model & 147.2 & 0.3 & 4.0 & $25.40 \pm 0.29$ & $0.788 \pm 0.019$ \\
\hline Predicted solution & 155.0 & 0.4 & 5.0 & 28.19 & - \\
\hline Experimental results & 155.0 & 0.4 & 5.0 & $27.38 \pm 0.09$ & $0.835 \pm 0.014$ \\
\hline $\begin{aligned} \text { Note: } & \text { a Palm oil mill } \\
& \text { b Chlorophyll- } \\
& { }^{\text {c }} \text { Specific grow }\end{aligned}$ & $\begin{array}{l}\text { ent concentrat } \\
\text { te. }\end{array}$ & & & & \\
\hline
\end{tabular}

optimised condition is based on high irradiance and aeration rate, both of which may increase the cost of biomass production. In an outdoor system, light is freely available and only the cost of providing aeration is an issue. This cost can be offset by using a higher concentration of $\mathrm{CO}_{2}$ (Zhang et al., 2002), which can be sourced from flue gas from power plants and provided at low aeration rate $(0.2 \mathrm{vvm})$ (Praveenkumar et al., 2014) or from biogas units used for anaerobic digestion of POME (Phang, 1990). The RSM optimised conditions in this study can serve as the basis for further study in outdoor cultivation of microalgae in POME.

\section{Lipid Content and Fatty Acid Profile}

As shown in Table 6, the lipid contents of C. vulgaris UMACC001 cultivated in POME varied from 7.4 to $29.5 \mathrm{wt} \%$ (percentage by dry weight). High biomass production associated with higher range of lipid contents $(>20 \mathrm{wt} \%)$ was observed in the combined conditions of high irradiance and high POME concentration (run \#6, 8, 9, and optimal). The higher lipid content is probably due to enhanced synthesis of neutral lipids in particular the triglycerides, which serve as stored energy contributed by the excessive supply of electrons which result from the over-reduced photosynthetic electron transport chain under high light condition (He et al., 2015). The lipid accumulation can be further induced in a second stage of nitrogen depletion, after the first stage of biomass production in high nitrogen condition (He et al., 2015; Praveenkumar et al., 2014), to suppress the NADPH consumption in the amino acid synthesis pathways, leading to the formation of fatty acids (Mallick et al., 2012) that can be utilised for biodiesel production.

According to Knothe (2005), fuel properties such as cetane number, oxidative stability and cold flow, determine the quality of biodiesel and they are influenced by its fatty acid distribution. The fatty acid profiles of the $C$. vulgaris UMACC001 grown in POME for this work are summarised in Table 6. The major constituents comprised 57.0-91.7 $\mathrm{wt} \%$ ( $\mathrm{wt} \%$ as methyl esters) saturated fatty acids (SFA), 5.2$28.0 \mathrm{wt} \%$ monounsaturated fatty acids (MUFA) and 3.1-16.1 wt\% polyunsaturated fatty acids (PUFA). In most of the runs, the predominant SFA was palmitic acid (C16:0), followed by myristic acid (C14:0) and stearic acid (C18:0). High proportion of these SFA (57.0-91.7 wt \%) will give a high cetane number for better ignition and lesser formation of white smoke (Mallick et al., 2012), making the Chlorella lipids a good source of biodiesel. Studies showed that cetane number increases with increasing carbon chain length and decreasing degree of unsaturation (Knothe, 2005; Ramos et al., 2009). The fatty acids profile in this study was similar to that of FAME extracted from C. vulgaris with $57.2 \mathrm{wt} \%$ of SFA, 37.5 wt $\%$ of MUFA and $10.3 \mathrm{wt} \%$ of PUFA (Nascimento et al., 2013). However, at low temperature, the solidification of SFA occurs, resulting in clogging problems and major operational issues (Knothe, 2005). The low temperature properties become worse with increasing chain length of SFA (Nascimento et al., 2013; Ramos et al., 2009). Unsaturated fatty acids, which have low melting points, can improve this cold flow performance. In order to retain high cetane number and oxidative stability without negatively affect the cold flow, an ideal mix of C16:1, C18:1 and C14:0 in the mass ratio of 5:4:1 is recommended (Schenk et al., 2008). Ramos et al. (2009) has also reported an optimum concentration range of MUFA $(>50 \mathrm{wt} \%)$ to fulfil the similar requirements. The lipids obtained from Chlorella cultivated in POME in the present study, is dominated by SFA ( $57.0 \mathrm{wt} \%)$ and MUFA (26.9 wt\%) which satisfy the biodiesel quality requirements. On the other hand, the abundance of unsaturated fatty acids reduces the cetane number and oxidative stability of biodiesel. Other than the influences from external factors such as air, heat and metals, the abundance of double bonds in the compounds make them prone to autooxidation during storage, causing the fuel to eventually deteriorate (Knothe, 2005). Table 6 shows a significant amount of PUFA is present consisting mainly of linoleic (C18:2), linolenic (C18:3) and eicosapentaenoic (C20:5) acids. The amount of C18:3 obtained in this study was $<5 \%$ for most of the runs, which fulfilled the permissible level for C18:3 (<12 \%) according to the European EN14214 standard for biodiesel (Praveenkumar et al., 2014). A good quality biodiesel may be achieved by a mixed culture of selected microalgae, appropriate blending 


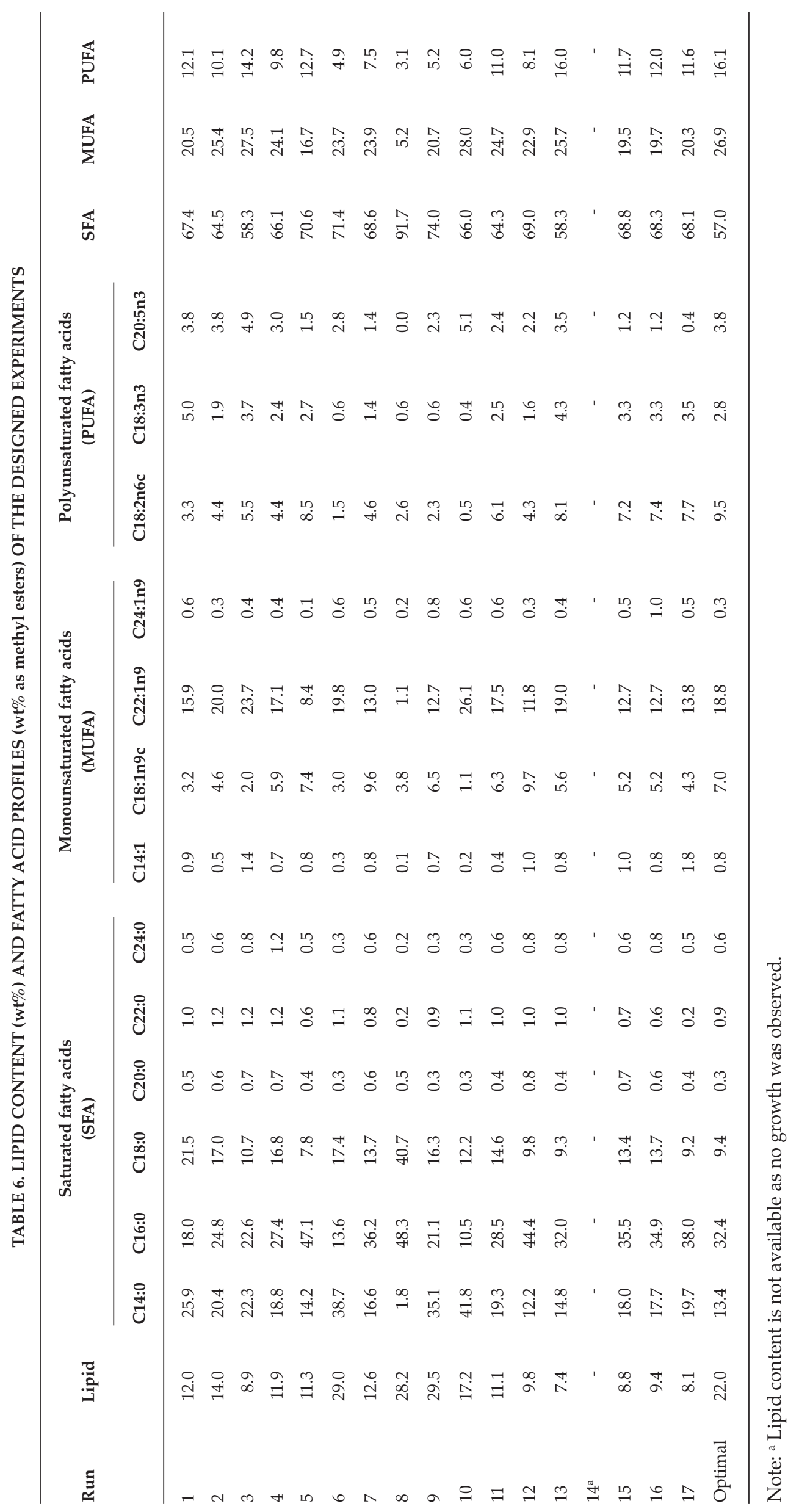


of oils from different monocultivated microalgae or with conventional diesel and the use of polymeric additives. In general, the lipid quality of C. vulgaris UMACC001 cultivated in POME can meet the biodiesel standards and is comparable to previous reports on C. vulgaris (Mallick et al., 2012) and microalgae cultivated in wastewater (Chinnasamy et al., 2010; Soydemir et al., 2016). C. vulgaris UMACC001 had been suggested as a potential strain serving as a biodiesel feedstock based on its fast growth ( $\mu=0.42$ per day) and high SFA content (68.2 wt\%) (Vello et al., 2014).

\section{CONCLUSION}

This study attempted to answer the question whether microalgae produced from POME can be a viable source for biodiesel. Optimising the growth rate of the desired algae is key to the potential. The study investigated the effect of sparger pore size and aeration rate, two important operating conditions, on the $\varepsilon, k_{\mathrm{L}} a$ and $R e$ in 5-litre annular photobioreactors. The results showed that the sparger with the $1 \mathrm{~mm}$ pore diameter produced the highest value of $k_{\mathrm{L}} a$. This was therefore selected to optimise biomass production. The findings further concluded that at least $0.2 \mathrm{vvm}$ of aeration was required to ensure sufficient turbulence to achieve adequate mixing and $\mathrm{CO}_{2}$ supply. The optimisation study employed a five-level CCD in RSM whereby the growth of C. vulgaris UMACC001 in the photobioreactors was evaluated using three factors, i.e. irradiance, aeration rate and POME concentration. The biomass production was significantly affected by POME concentration and irradiance, whereas the aeration rate affected the $\mu$. Chl- $a$ content increased at elevated irradiance level while maintaining the aeration rate and POME concentration at the central region of the design range. Maximal Chl- $a$ content was achieved at $155 \mu \mathrm{mol} \mathrm{m} \mathrm{m}^{-2} \mathrm{~s}^{-1}$ irradiance, $5 \%$ POME and $0.40 \mathrm{vvm}$ aeration. The findings were proved useful to investigate outdoor production using annular photobioreactors in the tropical region where there is strong sunlight. The biomass production and fatty acid profiles provided strong indications of the potential use of POME in culturing microalgae for biodiesel production in a cost-saving and environmental-friendly manner.

\section{ACKNOWLEDGEMENT}

The authors acknowledge the funding given by MPOB in collaboration with the Institute of Ocean and Earth Sciences (IOES), Universiti Malaya through Project No: 55-02-03-1054. The research also received financial support from Universiti Malaya's Postgraduate Research Fund
No: PV141-2012A and Knowledge Management Grant No: RP001O-13SUS.

\section{REFERENCES}

ANJOS, M; FERNANDES, B D; VICENTE, A A; TEIXEIRA, J A and DRAGONE, G (2013). Optimization of $\mathrm{CO}_{2}$ bio-mitigation by Chlorella vulgaris. Bioresource Technology, 139: 149-154.

APHA; AWWA and WEF (2012). Standard Methods for the Examination of Water and Wastewater. Washington DC, APHA.

BLIGH, E G and DYER, W J (1959). A rapid method of total lipid extraction and purification. Canadian J. Biochemistry and Physiology, 37(8): 911-917.

CHIN, M J; POH, P E; TEY, B T; CHAN, E S and CHIN, K L (2013). Biogas from palm oil mill effluent (POME): opportunities and challenges from Malaysia's perspective. Renewable and Sustainable Energy Reviews, 26: 717-726.

CHINNASAMY, S; BHATNAGAR, A; CLAXTON, $\mathrm{R}$ and DAS, K C (2010). Biomass and bioenergy production potential of microalgae consortium in open and closed bioreactors using untreated carpet industry effluent as growth medium. Bioresource Technology, 101(17): 6751-6760.

CHISTI, Y (1989). Airlift Bioreactors. Elsevier, London.

CONVERTI, A; LODI, A; DEL BORGHI, A and SOLISIO, C (2006). Cultivation of Spirulina platensis in a combined airlift-tubular reactor system. Biochemical Engineering J., 32(1): 13-18.

FAN, L H; ZHANG, Y T; CHENG, L H; ZHANG, L; TANG, D S and CHEN, H L (2007). Optimization of carbon dioxide fixation by Chlorella vulgaris cultivated in a membrane-photobioreactor. Chemical Engineering \& Technology, 30(8): 1094-1099.

HABIB, M A B; YUSOFF, F M; PHANG, S-M and MOHAMED, S (2003). Growth and nutritional values of Moina micrura fed on Chlorella vulgaris grown in digested palm oil mill effluent. Asian Fisheries Science, 16: 107-119.

HE, Q; YANG, H; WU, L and HU, C (2015). Effect of light intensity on physiological changes, carbon allocation and neutral lipid accumulation in oleaginous microalgae. Bioresource Technology, 191: 219-228.

ICHIHARA, K and FUKUBAYASHI, Y (2010). Preparation of fatty acid methyl esters for gas-liquid chromatography. J. Lipid Research, 51(3): 635-640. 
KIM, J; LEE, J-Y and LU, T (2014). Effects of dissolved inorganic carbon and mixing on autotrophic growth of Chlorella vulgaris. Biochemical Engineering J., 82: 3440 .

KIM, W; PARK, J; GIM, G; JEONG, S-H; KANG, C; KIM, D-J and KIM, S (2012). Optimization of culture conditions and comparison of biomass productivity of three green algae. Bioprocess and Biosystems Engineering, 35(1): 19-27.

KNOTHE, G (2005). Dependence of biodiesel fuel properties on the structure of fatty acid alkyl esters. Fuel Processing Technology, 86(10): 1059-1070.

LAVENS, P and SORGELOOS, P (1996). Manual on the Production and Use of Live Food for Aquaculture., Food and Agriculture Organization of the United Nations, Rome.

LIM, S-L; CHU, W-L and PHANG, S-M (2010). Use of Chlorella vulgaris for bioremediation of textile wastewater. Bioresource Technology, 101(19): 73147322.

LOH, S K; LAI, M E; NGATIMAN, M; LIM, W S; CHOO, Y M; ZHANG, Z and SALIMON, J (2013). Zero discharge treatment technology of palm oil mill effluent. J. Oil Palm Res. Vol. 25(3): 273-281.

LOH, S K; VIJAYA, S and NGATIMAN, M (2012). Oil Palm Biomass Energy Resource Data. MPOB, Bangi. p. $1-3$.

MALLICK, N; MANDAL, S; SINGH, A K; BISHAI, $\mathrm{M}$ and DASH, A (2012). Green microalga Chlorella vulgaris as a potential feedstock for biodiesel. J. Chemical Technology \& Biotechnology, 87(1): 137-145.

MUSTAFA, E-M; PHANG, S-M and CHU, W-L (2012). Use of an algal consortium of five algae in the treatment of landfill leachate using the high-rate algal pond system. J. Applied Phycology, 24(4): 953963.

MYERS, R and MONTGOMERY, D (1995). Surface Methodology: Process and Product Optimization Using Designed Experiments. Wiley-Interscience, New York.

NASCIMENTO, I; MARQUES, S; CABANELAS, I; PEREIRA, S; DRUZIAN, J; DE SOUZA, C; VICH, D; DE CARVALHO, G and NASCIMENTO, M (2013). Screening microalgae strains for biodiesel production: lipid productivity and estimation of fuel quality based on fatty acids profiles as selective criteria. Bioenergy Research, 6(1): 1-13.

NEOH, C; YAHYA, A; ADNAN, R; ABDUL MAJID, Z and IBRAHIM, Z (2013). Optimization of decolorization of palm oil mill effluent (POME) by growing cultures of Aspergillus fumigatus using response surface methodology. Environmental Science and Pollution Research, 20(5): 2912-2923.

NG, F-L; PHANG, S-M; PERIASAMY, V; YUNUS, K and FISHER, A C (2014). Evaluation of algal biofilms on indium tin oxide (ITO) for use in biophotovoltaic platforms based on photosynthetic performance. PLOS ONE, 9(5): e97643.

NICHOLS,HW and BOLD, HC(1965). Trichorsarcina polymorpha gen.et sp. nov. J. Phycology, 1: 34-38.

NWUCHE, C O; EKPO, D C; EZE, C N; AOYAGI, $\mathrm{H}$ and OGBONNA, J C (2014). Use of palm oil mill effluent as medium for cultivation of Chlorella sorokiniana. British Biotechnology J., 4(3): 305-316.

PALANISAMI, $S$; KANNAN, $\mathrm{K}$ and LAKSHMANAN, U (2012). Tannase activity from the marine cyanobacterium Phormidium valderianum BDU140441. J. Applied Phycology, 24(5): 1093-1098.

PHANG, S-M (1990). Algal production from agroindustrial and agricultural wastes in Malaysia. Ambio, 19(8): 415-418.

PHANG, S-M and CHU, W L (1999). University of Malaya Algae Culture Collection (UMACC), Catalogue of Strains. Institute of Postgraduate Studies, University of Malaya, Kuala Lumpur.

PHANG, S-M; CHUI, Y Y; KUMARAN, G; JEYARATNAM, S and HASHIM, M A (2001). High rate algal ponds for treatment of wastewater - a case study for the rubber industry. Photosynthetic Microorganisms in Environmental Biotechnology (Kojima, H and Lee, Y K eds.). Springer, Hong Kong.

PHANG, S-M and ONG, K C (1988). Algal biomass production in digested palm oil mill effluent. Biological Wastes, 25(3): 177-191.

PIROUZI, A; NOSRATI, M; SHOJAOSADATI, S A and SHAKHESI, S (2014). Improvement of mixing time, mass transfer, and power consumption in an external loop airlift photobioreactor for microalgae cultures. Biochemical Engineering J., 87: 25-32.

PONRAJ, M and DIN, M F M (2013). Effect of light/ dark cycle on biomass and lipid productivity by Chlorella pyrenoidosa using palm oil mill effluent (POME). J. Scientific \& Industrial Research, 72(11): 703-706.

PRAVEENKUMAR, R; KIM, B; CHOI, E; LEE, K; CHO, S; HYUN, J-S; PARK, J-Y; LEE, Y-C; LEE, H; LEE, J-S and OH, Y-K (2014). Mixotrophic cultivation of oleaginous Chlorella sp. KR-1 mediated by 
actual coal-fired flue gas for biodiesel production. Bioprocess and Biosystems Engineering, 37(10): 20832094.

RAMOS, M J; FERNÁNDEZ, C M; CASAS, A; RODRÍGUEZ, L and PÉREZ, Á (2009). Influence of fatty acid composition of raw materials on biodiesel properties. Bioresource Technology, 100(1): 261-268.

REYNA-VELARDE, R; CRISTIANI-URBINA, E; HERNÁNDEZ-MELCHOR, D J; THALASSO, F and CAÑIZARES-VILLANUEVA, R O (2010). Hydrodynamic and mass transfer characterization of a flat-panel airlift photobioreactor with high light path. Chemical Engineering and Processing: Process Intensification, 49(1): 97-103.

RICHMOND, A (1986). Handbook of Microalgal Mass Culture. Boca Raton, Florida, CRC Press, Inc.

RYU, H J; OH, K K and KIM, Y S (2009). Optimization of the influential factors for the improvement of $\mathrm{CO}_{2}$ utilization efficiency and $\mathrm{CO}_{2}$ mass transfer rate. $J$. Industrial and Engineering Chemistry, 15(4): 471-475.

SCHENK, P; THOMAS-HALL, S; STEPHENS, E; MARX, U; MUSSGNUG, J; POSTEN, C; KRUSE, $O$ and HANKAMER, B (2008). Second generation biofuels: high-efficiency microalgae for biodiesel production. Bioenergy Research, 1(1): 20-43.

SFORZA, E; SIMIONATO, D; GIACOMETTI, G M; BERTUCCO, A and MOROSINOTTO, T (2012). Adjusted light and dark cycles can optimize photosynthetic efficiency in algae growing in photobioreactors. PLOS ONE, 7(6): e38975.

SIERRA, E; ACIÉN, F G; FERNÁNDEZ, J M; GARCÍA, JL; GONZÁLEZ, C and MOLINA, E(2008). Characterization of a flat plate photobioreactor for the production of microalgae. Chemical Engineering J., 138(1-3): 136-147.

SOYDEMIR, G; KERIS-SEN, U; SEN, U and GUROL, $M$ (2016). Biodiesel production potential of mixed microalgal culture grown in domestic wastewater. Bioprocess and Biosystems Engineering, 39(1): 45-51.

SPOLAORE, P; JOANNIS-CASSAN, C; DURAN, E and ISAMBERT, A (2006). Commercial applications of microalgae. J. Bioscience and Bioengineering, 101(2): 87-96.

STRICKLAND, J D H and PARSONS, T R (1972). A Practical Handbook of Seawater Analysis. Fisheries Research Board of Canada. Ottawa.

SUBRAMANIAM, V; MA, A N; $\mathrm{CHOO}, \mathrm{Y}$ M and NIK SULAIMAN, N M (2008). Environmental performance of the milling process of Malaysian palm oil using the life cycle assessment approach. American J. Environmental Sciences, 4(4): 310-315.

SUKUMARAN, P; NULIT, R; ZULKIFLY, S; HALIMOON, N; OMAR, H and ISMAIL, A (2014). Potential of fresh POME as a growth medium in mass production of Arthrospira platensis. Int. J. Curr. Microbiol. Appl. Sci., 3(4): 235-250.

TANG, D; HAN, W; LI, P; MIAO, X and ZHONG, $\mathrm{J}$ (2011). $\mathrm{CO}_{2}$ biofixation and fatty acid composition of Scenedesmus obliquus and Chlorella pyrenoidosa in response to different $\mathrm{CO}_{2}$ levels. Bioresource Technology, 102(3): 3071-3076.

THANI, M I; HUSSIN, R; IBRAHIM, W R W and SULAIMAN, M S (1999). Industrial Processes and the Environment (Handbook No.3): Crude Palm Oil Industry. Department of Environment, Kuala Lumpur.

VAIRAPPAN, C S and ANG, M Y (2008). Palm oil mill effluent (POME) cultured marine microalgae as supplementary diet for rotifer culture. J. Applied Phycology, 20: 603-608.

VELLO, V; PHANG, S-M; CHU, W-L; ABDUL MAJID, N; LIM, P-E and LOH, S K (2014). Lipid productivity and fatty acid composition-guided selection of Chlorella strains isolated from Malaysia for biodiesel production. J. Applied Phycology, 26(3): 1399-1413.

WU, T Y; MOHAMMAD, A W; JAHIM, J M and ANUAR, N (2010). Pollution control technologies for the treatment of palm oil mill effluent (POME) through end-of-pipe processes. J. Environmental Management, 91: 1467-1490.

YANG, $\mathrm{Y}$ and GAO, $\mathrm{K}$ (2003). Effects of $\mathrm{CO}_{2}$ concentrations on the freshwater microalgae, Chlamydomonas reinhardtii, Chlorella pyrenoidosa and Scenedesmus obliquus (Chlorophyta). J. Applied Phycology, 15(5): 379-389.

ZHANG, K; KURANO, $\mathrm{N}$ and MIYACHI, S (2002). Optimized aeration by carbon dioxide gas for microalgal production and mass transfer characterization in a vertical flatplate photobioreactor. Bioprocess and Biosystems Engineering, 25(2): 97-101.

ZHENG, H; GAO, Z; YIN, F; JI, X and HUANG, $\mathrm{H}$ (2012). Effect of $\mathrm{CO}_{2}$ supply conditions on lipid production of Chlorella vulgaris from enzymatic hydrolysates of lipid-extracted microalgal biomass residues. Bioresource Technology, 126: 24-30. 